\author{
Visión Electrónica \\ Más que un estado sólido \\ https://doi.org/10.14483/issn.2248-4728
}

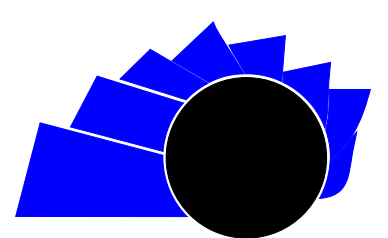

VISIÓN ELECTRÓNICA

A CONTEXT VISION

\title{
Topography, the primary basis of the reconstruction of a traffic accident
}

\author{
Topografía, la base principal de la reconstrucción de un accidente de \\ tráfico
}

Fabio Nelson Rodríguez-Ortega 1

INFORMACIÓN DEL ARTÍCULO

Historia del artículo:

Enviado: 29/05/2020

Recibido: 06/06/2020

Aceptado: 02/08/2020

\section{Keywords:}

Forensic physics

Hypothesis

Investigation

Topography

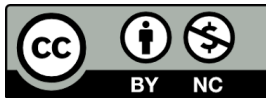

Palabras clave:

Física forense

Hipótesis

Investigación

Topografía

\begin{abstract}
The following document applied to the investigation and reconstruction of traffic accidents, seeks to conceptualize the serious errors that exist in many public and private institutions when considering that the reconstruction of a traffic accident is to determine the vehicle speed, with one or more physical equations or in the worst case, a 2D or 3D animation of an alleged traffic accident dynamics, as well as explain confused concepts and procedures in the field of criminal investigation, specifically in the reconstruction of traffic accidents. Starting from the premise that the reconstruction of a violent in traffic death essentially seeks the identification and clearancing of variables in the investigation, also exposing not very clear concepts regarding the topic of interest; from the above, important errors are determined in the concepts that we have of what is a forensic reconstruction, the hypotheses that are used in the sketch of traffic accidents in Colombia and the great errors that exist in the matter of fixing physical evidence (EF).
\end{abstract}

\section{RESUMEN}

El siguiente documento aplicado a la investigación y reconstrucción de accidentes de tránsito, busca conceptuar los graves errores que existen en muchas instituciones públicas y privadas al considerar que la reconstrucción de accidente de tránsito es determinar la velocidad vehicular, solamente con el despeje de una o varias ecuaciones físicas o en el peor de los casos, una animación en $2 \mathrm{D}$ o $3 \mathrm{D}$ de una presunta dinámica de siniestro de tránsito, así mismo explicar conceptos y procedimientos confundidos en el ámbito de la investigación criminal, propiamente en la reconstrucción de accidentes de tránsito. Partiendo de la premisa que la reconstrucción de una muerte violenta busca en esencia el despeje de variables en la investigación, exponiendo además conceptos no muy claros referente al tema de interés; de lo anterior se determinan errores importantes en los conceptos que tenemos de que es una reconstrucción forense, las hipótesis que se utilizan en los croquis de accidentes de tránsito en Colombia y los grandes errores que existen en materia de fijación de evidencia física (EF).

\footnotetext{
${ }^{1}$ Specialist in forensic sciences, Universidad Libre, Colombia. BSc. in Topographical engineering and topography technologist, Universidad Distrital Fráncico José de Caldas, Colombia. Technician in criminology and forensic sciences, Escuela de Investigación, Criminalística y Criminología Lombroso, Colombia. Expert technician in motor vehicles - traffic accidents and expert technician in forensic ballistics Instituto Superior Unificado de Criminalística, Investigación y Tecnología La Sabana LTDA, Colombia. Graphic Designer, Universidad La Gran Colombia, Colombia. Mathematics and physics (c), Universidad Católica de Manizales, Colombia. Current position: Coordinator of the engineering area at Unidad de Investigación Forense y Criminalística Profesional, Colombia. Professor at Universidad Distrital Francisco José de Caldas, Colombia. E-mail: fnrodriguezo@correo.udistrital.edu.co uiforensicol@gmail.com
} 


\section{Introduction}

In Colombia, as in many other countries, it is believed that to reconstruct a traffic accident is to transcribe the description of the place of events of the report prepared by the traffic agent, to re-diagram the sketch of the traffic accident without more minimum the slightest verification process and resolving "one" or in very few cases several physical equations in order to reconstruct, that is; simply calculate speeds. This without the slightest argument of the scientific basis of why a certain applied physical model is used, and with this the rebuilder determines with a touch of deity the responsibility of some of the procedural subjects within theinvestigation, leaving out absolutely many of the variables that could have influenced the dynamics of the incident.

Currently, in the investigation and reconstruction of traffic accidents in Colombia and other countries, a mistaken idea of what it is in essence is presented, since the reconstruction of a traffic accident does not is solve "calculating speeds", with the simple solve of one or various physical equations as some people believe and indicate and that only a professional in physics can do in order to determine the possible dynamics of the facts; this is simply the physical- mathematical assessment of the case based on incomplete information that can mislead the administration of justice and, even more serious, to make an animation in any current technique $(2 \mathrm{D}, 3 \mathrm{D}$, augmented reality, $\mathrm{P}-360^{\circ}$, others) in order to show the possible happened without scientific basis, but it is what is observed in many cases of accident reconstruction.

Nor does it indicate the responsibilities of some of those involved without technical foundations and with "hypothesis" theories without scientific support to support these assertions; forensic reconstructive analysis goes further, where according to the technology and capabilities of the rebuilder, the latter must evaluate and clear the greater number of variables, collecting the largest set of information in order to demonstrate a certain hypothesis. Not to leave everything in the hands of a physical equation and thus point out with a touch of omnipotence to a certain procedural subject. But in Colombia, as in many other countries, many of the experts who claim to do forensic reconstruction, do not even go to the scene to clear variables, they do not even bother to verify if the sketch of the accident is right or wrong doing, performing physical analysis in many cases wrong in employment to poorly elaborated sketches.

\section{Theoretical framework}

\subsection{Reconstruction}

According to [1] reconstruction is: "action and effect of reconstructing something abstract or material"; therefore, the reconstruction of a traffic accident should seek to clear as many variables as possible that influenced the dynamics of the road accident, it is not in any way, only the physical-mathematical part and is what was commonly observed in the calls Accident Reconstructions Traffic "RAT". Misnamed Traffic Accident Reconstructions performed by some private and state companies in Colombia.

\subsection{Hypothesis}

According to [2] hypothesis is: "it is an assumption of something possible or impossible to derive a Consequence", a concept confused in many places in Latin America, as this situation brings with it aberrant problems in the administration of justice, depending on that a hypothesis is something that is supposed and given a certain degree of possibility to extract an effect or consequence from it, its validity depends on being subjected to various tests, based on elaborate theories that can be scientifically verified; but in Colombia, traffic accident rebuilders take these hypotheses as an irrefutable scientific element; without considering at all that an investigation report of the incident is prepared by a traffic agent who normally has arrived several minutes after the events occurred, is not, nor is he a direct witness to the events (dynamics) and the hypothesis born from This official is an assumption without being subjected to any scientific verification process. It is very serious, since some administrators of justice, omit hypothesis verification processes and assume that this is the final scientific conclusion in various traffic accidents.

Figure 1 shows a sketch of a traffic accident No. C-00058521424 with code 105: overtaking in a prohibited area and code 138: lack of caution due to fog, rain or smoke.

Figure 1: Traffic accident hypothesis [3].

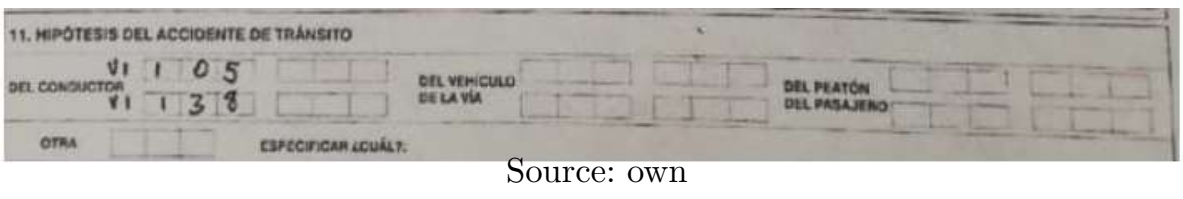


Figure 2: Sketch of a traffic accident [4].

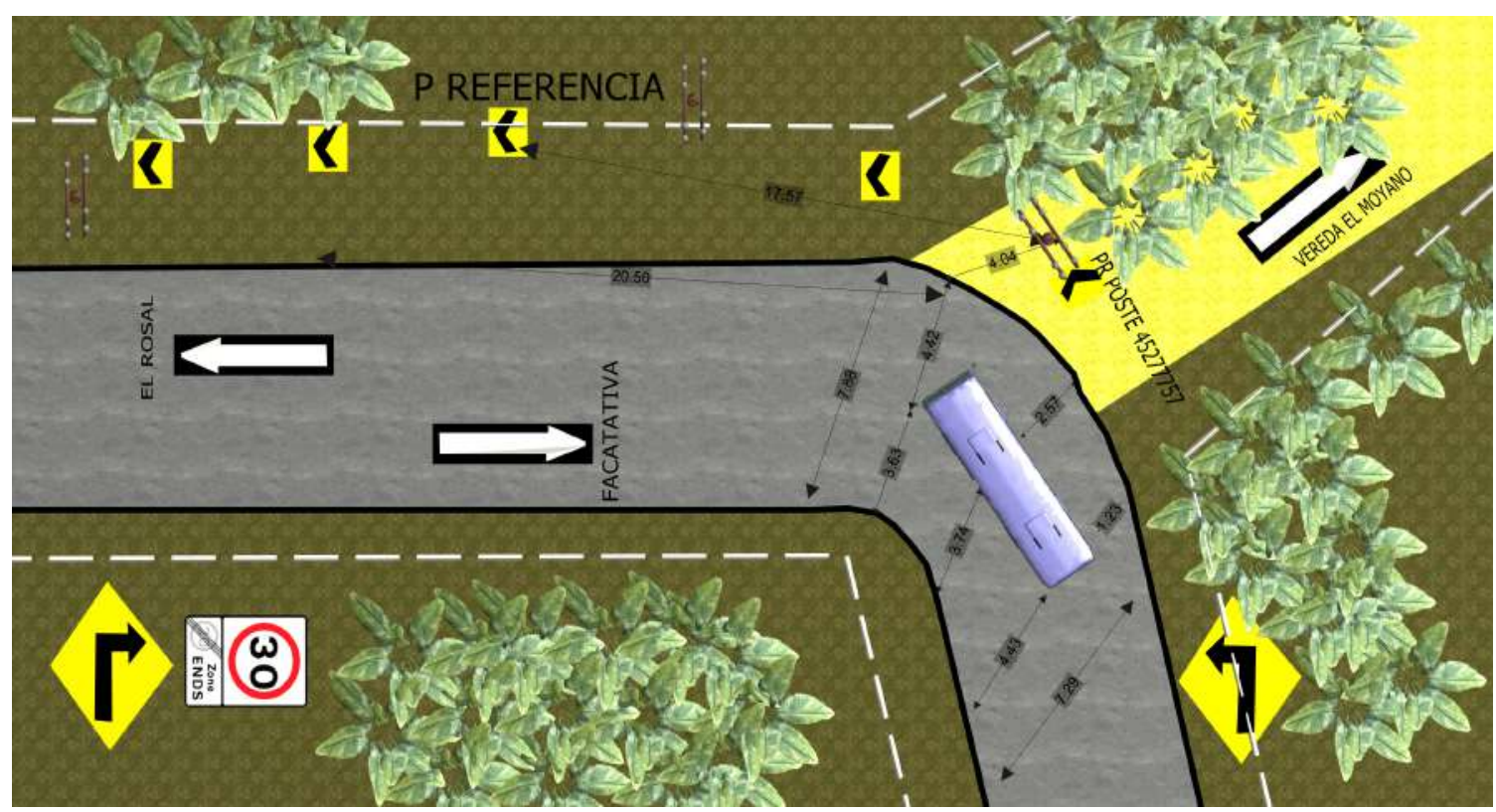

Source: own

\subsection{Sketch of the incident}

In Colombia the institution that designs the technical guidelines in violent death procedures is the Attorney General's Office - FGN (2003), where its topographic manual of manual procedures in spatial location of EF and / or EMP has deficiencies, in that it does not explain the procedures, considerations, methodologies and their application [4]; the foregoing being a direct consequence and reflected in the topographical sketches and blueprints that the competent authority in the matter of traffic accidents emanates, therefore many private institutions and the same institutions state ones overlook the verification of tolerance, precision and quality of the orthometric fixation performed by the authority that locates the physical evidence; This activity (metric sketch verification) should be mandatory for all types of analytical reconstruction of traffic accidents, whether in a public or private institution.

Since this allows determining if the sketch is functional for forensic physics processes, however, it has been shown that some public and private institutions that carry out physical analyzes of traffic accidents do not seem to care if the sketch is reliable or not in planimetric methodology and quality of measurement, from there arises an important question: wouldn't physical- mathematical calculations be wrong, if the sketch reveals insurmountable measurement errors. Remember that in most cases, the fundamental basis of forensic physics processes is the sketch of the traffic accident (CAT).

Explaining that it is a true reconstruction of a traffic accident and the objections to take into account in the face of the considerations outlined on the hypotheses, errors in the planimetricfixation of physical evidence and explain that the speeds are not in any way a reconstruction process forensic. This is the object of research and presentation of this document. Figure 2 shows a sketch of a traffic accident with a wrong EF fixation process.

\section{Methodology}

The first methodological step in the development of the research project was to determine the concept of reconstruction and that it should lead to a reconstruction of traffic accidents, also found another accepted concept, to reconstruct: "Reproduction or memory of all the actions and circumstances of a past event through data, statements, etc., to complete your knowledge." According to [5] and a reconstruction of an accident, you should at least consider the following points:

- Verification of quality in measurement of the sketch PONAL-CTI-others.

- Topographic survey of resolution to the second to verify geometric and structural components of the place of the events. 
- Make photographic-videographic fixation of the place of the events and EF. (Technical sheets, metadata, crudes, supports, photogrammetry calculations, other.)

- Perform verification of natural or artificial lighting conditions at the scene. (Color temperature calculations, distancia of ilumination, other)

- Verifing vehicle lighting conditions (distance and lighting coverage angles).

- Determine the components and technical characteristics of the vehicle as well as the structural damages (impact angle, impact direction, damage depth).

- Carry out analysis of conditions of pedestrian, vehicular flow (traffic and transport).

- Clear variables of traffic light cycles.

- Determine the spatial campometry factors of those involved.

- Determine masks of visual obstruction.

- Perform analysis and localization of lesions in 3D model for comparison with impact dynamics, crushing and / or expulsion, others.

- Apply photography of the area of the events, with special photographic apara terrestrial photogrammetry.

- Carry out pavement analysis.

- Carry out the road engineering analysis solve all the variables of the road (slopes, can't vertical, radius of curvature, length of the curve, others).

- Verification of the location of people through triangulation of calls.

- Carry out a mathematical physical analysis of the dynamics of the events . accident phases"with scientific foundations and an explanation of the physical-mathematical model used.

Among other technical activities in the area of reconstruction of traffic accidents, after resolve all these minimum variables if one can speak of "reconstruction".

A second step was to collect some reconstructions of traffic accidents or related documents issued by different institutions, a process that was carried out through consultation on the Internet, through common and academic search engines. The panorama was discouraging when observing that any mathematical

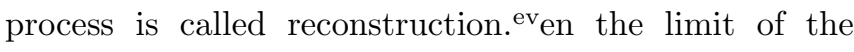
subjective, since not many other variables are not evaluated; but the great majority of consulted documents that although it is true are excellent in terms of physics or mathematics; they don't seem to care about the metric quality the sketch, it is an accident day or night, if there are visual obstacles due to road geometry, among many other variables. Examples of this are:

- Reconstruction of traffic accidents based on Biomechanical Analysis [6]

- Reconstruction of traffic accidents in cyclists [6]

- Theoretical model for the reconstruction of traffic accidents by computer [7]

- Physical and mathematical analysis of a traffic accident report [8]

- Accident reconstruction with telematic data [9]

- Reconstruction of traffic events [10]

- Road accidentology [11]

- Investigation of traffic accidents in Colombia [12]

- Manual of investigation and reconstruction of traffic accidents [13]

- The speed of projection and the speed of impact in the running over of a cyclist with a frontal vehicle [14]

- Traffic accident reconstruction manual [15]

- Development of a model for analytical reconstruction of a car collision [16]

- Accident reconstruction [17]

- Traffic accidents "reconstruction" [18]

- Reconstruction of a traffic accident to determine the speed with which vehicles interact with each other. [19]

As a third and vital action, we highlight the activity dedicated to forensic topography that for more than 5 years, I rate more than 105 manual sketches of traffic accidents in Colombia, where it was found that $96.5 \%$ are of low measurement quality, $78.4 \%$ of wrong application of planimetric fixing methods, $96.4 \%$ lack of technical elements constituting a sketch or topographic plan, as well as $100 \%$ of no technical supports for their work. [5] 


\subsection{Primary basis}

Because topography is the primary basis of any violent death reconstruction process, then, the sketch is the only document that records the spatial location "X, Y, Z, T" on the Earth's surface of physical evidence fixed the day of the occurrence of the events and when a sketch or flat does not show the MINIMUM precision and topographical quality, no physics-mathematics process or reconstruction of the traffic-ballistic accident or others is viable or credible; for what part of a serious, rude or insurmountable error. Unless ground photogrammetry (topography to the second of the place and special photographs) is carried out in order to overcome the shortcomings detected in the sketches made by the competent authority. Recalling that terrestrial photogrammetry is a distance recovery technique through terrestrial or aerial photographs by specialized technical methods, clearing the minimum and following variables.

- The shooting distance from the object or plane to be dimensioned.

- Record of measurement standard, climber IN THE IMAGE TO CLIMB.

- Vertical and horizontal angle of the shot subject to scale.

- Metadata of the photograph according to its capture format.

- Calculation of image scale versus millimeter topography of the terrain.

- Radiometric quality calculations and reports of the image used.

- GSD of the image with which indicates that there is an error in measurement (REQUIRED).

- The shooting height in relation to the ground of the base image for trigonometric and angular clearing of image capture in proportion to the photographic depth of field.

- And most importantly, the image to make this important statement must consider the aspect of cross-shot direction.

- By not evacuating these and other variables, errors of observation and appreciation are easily incurred.

The topography solves many more variables than the same physics or mathematics, it is not based on subjective information such as the reaction time and perception of a driver; the topography measures in the place of the facts impossible variables for physics, being the work of measurement much richer in clearing influential variables in a violent death.

\section{Results}

The information analysis project has been developed in the Forensic Investigation Unit, a private laboratory for forensic engineering; where analyzing the work of accident reconstruction in the last 10 years, it has been observed that the calculation of speed in a certain accident is called reconstruction. Based on the best scenarios of reports of the place of the facts prepared by the traffic agent, photographs, an unverified sketch, vehicle damage and in some cases the evaluation of injuries; without considering many other variables emerging from the scene, and topography being the only science capable of collecting this information, post-processing it and yielding vital information for the process of reconstructive analysis of the case.

When reviewing the cited documents, most of the above and many more consulted focus the concept of "reconstruction" on the calculation of speed, using different physical models. Noneof the above broadens the reconstruction landscape to external factors that can become much more important than the mathematical physical clearance of an equation.

Another important and even more worrisome result is the fact that many "rebuilders" take for granted; they consider with an unquestionable margin of scientific credibility, beyond all error, with a touch of analogy to scientific laws, laws of their own nature or irrefutable theorems. The fact that sketch of traffic accident is well performed; that is to say, some rebuilders who do not evaluate or question with another topographic procedure and statistical mathematical calculations the level of precision of a certain sketch, in fact many rebuilders do not even go to the place of the events even if they claim do it in their reports.

\section{Discussion}

It is completely contrary to a tautology, to affirm that a reconstruction of a traffic accident depends on the calculation of the speed of one or more vehicles, and is what is seen in different consultations, it seems to be the common and general, is what is believed. The speed calculation does NOT determine variables that the topography can solve, such as the refraction and reflection of light in an accident that occurred at night, or the distance traveled by a person in a certain 
crosswalk, it does not consider a geometric or structure affectation in the roads, estimates of real climatic factors, does not consider spatial obstacles and much less is a reconstruction credible when the topographic measurement quality is not evaluated, being the basis of all reconstructive principles.

Three nascent questions Three nascent questions in this discussion are: in this discussion are:

- How can you trust the reconstruction if you only evaluate the speed aspect, being just one of the many variables resulting from a traffic accident?

- How to trust physical-mathematical calculations, without knowing the level of precision of the sketch, planimetry, plan topographic or representation orthometric?

- If the sketch is poorly done, by graphing, measurement and orthometric closures, would the physical calculations not be wrong, in essence the reconstruction would not be wrong?

The main contribution made by this document is to understand that reconstruction is not only calculating speed, both the physics, photography, topography, mechanics, among other sciences; they provide valuable information for understanding what happened in a certain violent death. It is from my point of view as a professional in different scientific areas applied to the reconstruction of accident, a complete and absolute error to call accident reconstruction without resolve the greatest number of variables immersed in the time-space evolutionary process that is framed in an accident. Physics is only and just one of the many variables that exist in a traffic accident, forensic physics does not actually reconstruct the accident; if not, the compendium of all the areas that achieve this end.

Figure 3 shows the graphic output of the reconstructive process of a traffic accident.

\section{Conclusions}

It was possible to identify the definition of reconstruction and contrast it with the concept of reconstruction of a traffic accident, which does not coincide; that is to say, in the reconstructionof traffic accidents in many cases only the knowledge of the speed of one or more vehicles is sought, this being different from the purpose of rebuilding, which prevails in knowing the greatest number of variables in order to redo a fact.
Figure 3: 3D model, complete topography of the site [20].

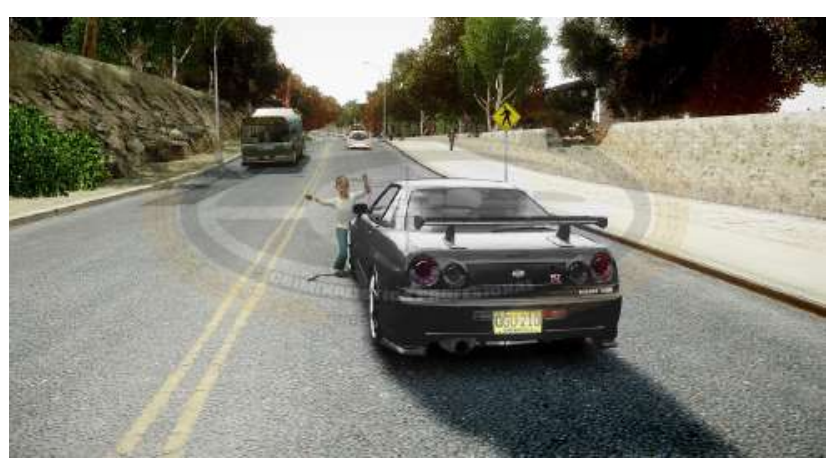

Source: own

It was possible to identify in the consultations carried out, as well as what has been seen in more than 10 years of professional experience in the field of investigation and reconstruction of traffic accidents, that many institutions that claim to do reconstruction, do not consider or seem not to care if the sketch fundamental basis of all physical process, it is well or poorly elaborated.

It was concluded regarding the prior investigation of the state of the art, that if there are some technical manuals of procedures, books, texts, guides or others, that deal with the basic notions in reconstruction of traffic accidents. But most of them have the calculation of speed as a reconstruction objective and physics mathematics as a central axis.

\section{Acknowledgments}

Thanks to the Professional Forensic Investigation and Criminalistics Unit UIFCP, as they were responsible for making a great contribution, which today is reflected in a process of scientific investigation directly contributing to the development of forensic science in Colombia and Latin America. The author wishes to express his gratitude to the many scholars who, over more than a century, have discovered, deciphered, translated and explained some forensic technical procedures, whose courtesy the author has been able to access the textual and graphic evidence in which This document is based.

\section{References}

[1] Real Academia Española, "Reconstrucción". [Online]. Available at: https://dle.rae.es/ reconstrucci $\%$ C3\%B3n

[2] Real Academia Española, "Hipótesis". [Online]. Available at: https://dle.rae.es/hip\%C3\% B3tesis 
[3] Policía Nacional de Colombia, "Croquis PONAL-Colombia No. C-00058521424", Fiscalía Facatativá-Cundinamarca, 2016.

[4] Policía Nacional de Colombia, "Croquis accidente de tránsito con errado proceso de fijación de EF", Alexander Villa Osorio, 2016.

[5] F. N. Rodríguez, "Manual de topografía aplicado a la investigación y reconstrucción de accidentes de tránsito", Boletín Semillas Ambientales, vol. 11, no. 2, pp. 68-80, 2017.

[6] G. Pequerul, "Reconstrucción de accidentes de tráfico basados en Análisis Biomecánicos", Centro Zaragoza, no. 56, 2013.

[7] J. Lozano, "Modelo teórico para la reconstrucción de accidentes de tráfico por ordenador", thesis PhD., E.T.S.I. Industriales (UPM), Spain, 1996.

[8] E. Urrutia Bermúdez, "Análisis físico y matemático de un informe de accidente de tránsito", Scientia et Technica, vol. 2, no. 45, pp. 192-195, 2010. https: //doi.org/10.22517/23447214.367

[9] Geotab, "Geotab transporte", 2016. [Online]. Available at: https://www.geotab.com/es/ reconstruccion-de-accidentes/

[10] J. A. Ramos, Reconstrucción de Hechos de Tránsito". [Online]. Available at: http: //www.institutoivia.com/cisev-ponencias/ analisis_accidentes_aa/jorge_ruiz.pdf

[11] B. Ávila González, "Accidentología vial - road accident analysis", Revista Infraestructura Vial, vol. 16, no. 28, pp. 44-50, 2014.

[12] Policía Nacional de Colombia, "Investigación de accidentes de tránsito en Colombia. Bogotá: Imprenta Nacional de Colombia, 2017. [Online]. Available at: https://www.policia.gov.co/file/ 187193/download?token=JuaAf5sw
[13] F. Toledo, "Manual de investigación y reconstrucción de accidentes de tráfico", Valencia, España. [Online]. Available at: https://imt.mx/images/files/SPC/ Convocatorias/Formatos/bibliografia/ Manual-investigacion-restriccion-accidentes\ -trafico.pdf

[14] A. O. García, "La velocidad de proyección y la velocidad de impacto en el atropellamiento de un ciclista con un vehículo frontal", 2003. [Online]. Available at: https:// forense.hpchile.cl/index.php/articulos/ 13-accidentologia-vial/66-la-velocidadde-proyeccion-y-la-velocidad-de-impacto-en\ -un-atropellamiento

[15] CesviMap. "Manual de reconstrucción de accidente de tráfico". [Online]. Available at: https: //www.cesvimap.com/centro-seguridad-vial/ es/fabricantes-automoviles/ investigacion-accidentes-fraude/ manual-reconstruccion-accidentes.jsp

[16] C. J. Gutiérrez, "Desarrollo De Un Modelo Para La Reconstruccion Analitica De La Colision Automovil - Automovil Con Efecto Rotacional Respecto Al Eje Vertical Del Movimiento Pos Impacto", thesis, Universidad Industrial de Santander, Colombia, 2008.

[17] J. Diez, "Reconstrucción de accidentes", Valladolid, España: Universidad de Valladolid, 2012.

[18] F. J. López, "Accidentes de tráfico reconstrucción", Sevilla, España: Universidad de Sevilla, 2005.

[19] P. Segura, W. Santana, "Física aplicada a la reconstrucción de accidente de tránsito para determinar la velocidad con que interactúan los vehículos entre sí", thesis, Instituto de estudios superiores academia de policías Walter Mendoza Martínez, 2006.

[20] UIFCP, "Reconstruction of sinister", Colombia, 2014. 